\title{
Sustainable Extensive On-Site Constructed Wetland for Some Bacteriological Reduction in Kitchen Greywater
}

\author{
Anwaruddin Ahmed Wurochekke ${ }^{1, a^{*}}$, Radin Maya Saphira Radin Mohamed ${ }^{2, b}$ \\ Siti Asmah Binti Lokman Halim ${ }^{3, c}$, Amir Hashim bin Mohd. Kassim ${ }^{4, d}$ \\ and Rafidah Binti Hamdan ${ }^{5, \mathrm{e}}$ \\ ${ }^{1,2,3,4,5}$ Faculty of Civil and Environmental Engineering, \\ Universiti Tun Hussien Onn Malaysia, \\ Locked Bag 101, 86400 Parit Raja, Batu Pahat.Johor, Malaysia \\ ayadembo02@yahoo.com, bmaya@uthm.edu.my, 'Asmah_Ihalim@yahoo.com, \\ damir@uthm.edu.my, ${ }^{e}$ rafidahh@uthm.edu.my
}

Keywords: Greywater, Kitchen, Constructed Wetland, Water Pollution, Lepironia Articulata

\begin{abstract}
Malaysia is experiencing water pollution crisis recently. In particular, greywater discharge directly to drains. Therefore, a greywater treatment system was designed to overcome this drain pollution. To investigate the operation and performance of the treatment system, constructed wetland was designed and builds for a small single household. Lepironia Articulata was chosen for populating wetland. The wetland was supplied with kitchen greywater. The selected house is appropriate because it lacks proper drainage system. This study evaluates the characteristic of kitchen greywater before and after treatment. The quality parameters of greywater that involve in this study are Total Coliform and E-coli. The range for reduction efficiency for Total Suspended Solid was 16.02 to 60.56 , E.coli was $26 \%$ to $51 \%$ and Total Coliform was $5 \%$ to $63 \%$. Generally, this study showed improved kitchen greywater quality before discharging to the nearest water body. The findings can be used significantly to enhance the knowledge in constructed wetland where it can serve as effective and integrated solutions for managing greywater discharging using control at source approach. A constructed wetland was best chosen due to its good visual impact, removal efficiency of organic material and other pollutant, as well economical.
\end{abstract}

\section{Introduction}

Various contaminations occurred such as water pollution cause by human carelessness and in proper disposal habit which is responsible to the environmental deterioration. The rivers were contaminated with various wastes whether domestic or industrial wastewater. Water is human necessity, missing its features and ability to prevail. According to United Stated Environmental Protection Agency, $70 \%$ of the earth's surface is covered with water [1]. However, only $1 \%$ of the water is potable. Therefore, it is very important to give it concern and responsible to preserve the natural treasure. In numerous up-coming countries, most of kitchen activities often elevate organic food leading the polluted water flow into rivers and stream prior to treatment [2]. Uncontrolled discharge of kitchen wastewater to land can cause eutrophication if it enters ponded surface water in great sufficient amount [3]. Apart from effects on water bodies, it is more sober when it also affects human health such as the incidence of infections. Eriksson [4] found kitchen wastewater had the highest Escherichia Coli (EC) owing to the contribution of supplier with treatment. Therefore, it is significant to provide measures of treating kitchen wastewater to save both environment and human health. According to Muzola, (2007) bacteria removal efficiency is related to inflow concentrations. Removal of indicator bacteria in wetlands also may be correlated with solids removal/reduction and hydraulic residence times [5].

Therefore, in this study, simple greywater $(\mathrm{GW})$ system was designed in one residential house at Parit Bengkok to overcome this problem. From reviews, best wastewater treatment result and easy to use especially in rural places were wetland [6]. For instance, recycle vertical flow constructed wetland (RVFCW) has been tested for GW treatment, particularly for small-scale decentralized use. 
Although this research is more to evaluation of GW reuse, the ability of the constructed wetland (CW) system to dissipate the pollutant was proven by compliance with USEPA standards for reuse [7]. However, CW are engineered system designed to simulate natural wetland and utilize same biological processes found in natural wetland ecosystems [8, 9]. Thus, horizontal subsurface flow applications shows that the use of $\mathrm{CW}$ provide an effective method for secondary treatment of onsite domestic wastewater [10]. These include sedimentation, mechanical filtration, adsorption, dieoff, predation, antibiotic production and excretion by plants and bacteria decay and exposure to stressful abiotic conditions such as $\mathrm{pH}$, temperature, and oxygen [11]. Therefore, this study seeks to provide appropriate biotreatment, investigate loading characteristic of kitchen $\mathrm{GW}$ in one unit village house and the performance of $\mathrm{CW}$ system in biological parameter such as E.coli and Total Coliform reductions.

\section{Methodology}

Greywater Treatment System. The treatment system has three compartments. For the first compartment, it was greywater influent collected from kitchen in to a black PVC tank of 120 liters. For the second stage as pre-treatment, the compartment was filled with river stone size of $20 \mathrm{~mm}$ diameter and was placed at the top to prevent material losses and holes blockage. The second and third layer was river stone with sizes $10 \mathrm{~mm}$ and $5 \mathrm{~mm}$ diameter accordingly while the bottom layer was filled with sand to trap the suspended solid. These media was separated using wire mesh. It was designed to prevent the filter materials from mixing with each other and ease to remove for some maintenance work. Meanwhile for the last compartment, it was the horizontal mini CW that consist gravel sizing $20 \mathrm{~mm}$ to $30 \mathrm{~mm}$ diameter and Lepironia Articulata plant. The compartments were connected together using PVC pipe. The flow of kitchen greywater was by gravity from storage tank to pre-treatment system and lastly to mini $\mathrm{CW}$ and extended treatment. The Lepironia Articulata plant was kept inside the compartment and then saturated with kitchen greywater for two weeks. These give time for microorganism to grow before experiment work so as to be capable of absorbing the pollutants/reduce biological oxygen demand (BOD) and chemical oxygen demand (COD) through the plant roots. The reason of choosing this type of plant is; it proves that Lepironia Articulata succeeded in removing 50\% of TSS from toilet and basin greywater [12]. Figure 1 shows the kitchen greywater treatment system that consist pre-treatment and secondary treatment. Face to face interview survey was conducted in the study area in parit $\mathrm{Hj}$ Rais, johor, Malaysia. Greywater was sampled three times in a day and replicates for the analysis of parameter like TSS were done in triplicate.

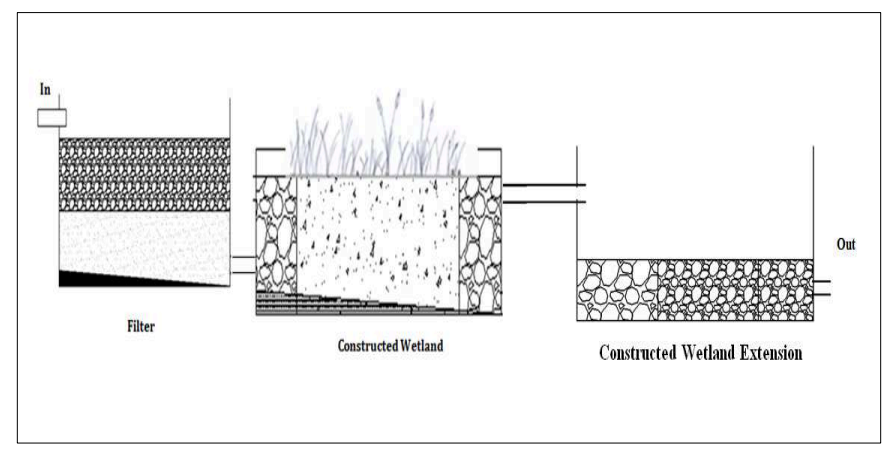

Figure 1: Pretreatment filter and Constructed Wetland plus Extended Wetland

\section{Result and Discussion}

Household Activity and Raw Kitchen Greywater. From the survey and interview session, there were 9 people at the study site consisting of 5 adults and 4 children ages 3 to 9 years old. The occupants usually bath 2/3 times a day. Because of the weather in Malaysia with temperature around $24^{\circ}$ and $39^{\circ}$ compare to other temperate countries caused people to bath more than 1 time per day. 
The occupants cook three times in a day morning, afternoon and night. They wash (laundry) morning and night daily. Physical parameters studied were $\mathrm{pH}$ values range from 4.15-5.75, total suspended solids range from $78 \mathrm{mg} / 1$ to $153 \mathrm{mg} / \mathrm{l}$. However, the $\mathrm{pH}$ values attained were close to neutral which is also toxic to bacterial survival and must have supported the increase of Feacal Coliforms [13].

Water Consumption Survey. From Table 1, total production of greywater was high in day 3 which conducted in afternoon on weekend day. At afternoon, house occupants performs the food preparation activities which involved washing raw materials such as fish, chicken and so on which is done in the kitchen sink which pose microbial contamination if discharge directly to drains. As presented in Figure 2, the overall result shows the high volume of greywater generated by bathroom at $52 \%, 37 \%$ of kitchen and $11 \%$ of laundry. From result shown the maximum greywater used was bathroom because the occupants shower twice a day for every person.

Table 1: Kitchen Greywater Loading for Three Days

\begin{tabular}{|c|c|c|c|}
\hline $\begin{array}{c}\text { Day } \\
\text { Time }\end{array}$ & $\begin{array}{c}\text { Day 1 } \\
(\mathrm{L})\end{array}$ & $\begin{array}{c}\text { Day 2 } \\
(\mathrm{L})\end{array}$ & $\begin{array}{c}\text { Day 3 } \\
(\mathrm{L})\end{array}$ \\
\hline $\begin{array}{c}\text { Morning } \\
(7 \mathrm{am}-12 \mathrm{pm})\end{array}$ & 50 & 55 & 60 \\
\hline $\begin{array}{c}\text { Afternoon } \\
(12 \mathrm{pm}-5 \mathrm{pm})\end{array}$ & 55 & 80 & 140 \\
\hline $\begin{array}{c}\text { Evening/night } \\
(5 \mathrm{pm}-7 \mathrm{pm})\end{array}$ & 60 & 140 & 100 \\
\hline Total & 230 & 275 & 300 \\
\hline
\end{tabular}

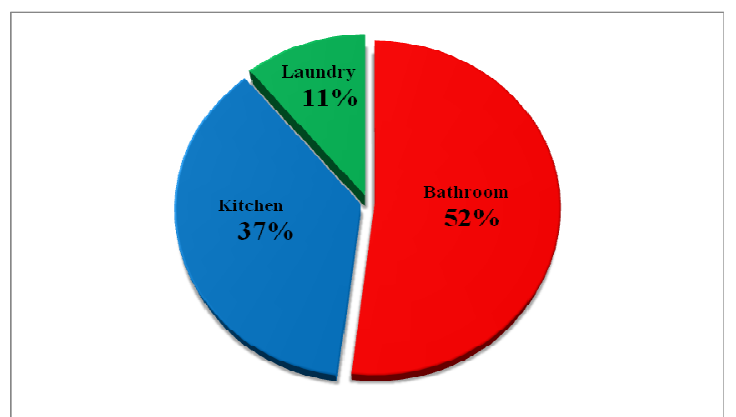

Figure 2: Percentages of Greywater Sources at Case Study

Physical Reduction. Removal of total suspended solids (TSS), oil and grease (O\&G) in greywater is important as they seriously contribute to environmental problems. TSS refers to the mass (mg) or concentration $\left(\mathrm{mg} \mathrm{L}^{-1}\right)$ of inorganic and organic matters held in the water column of a stream, river, lake or reservoir by turbulence [14]. Based on Figure 3, the percentage removal of TSS in 14 days of treatment attain $63.27 \%$ for pre-treatment system on day 9 while the lowest percentage was on day 4 with only $15.81 \%$ removal. While $\mathrm{CW}$ and extended treatment had the highest percentages on day 8 with $60.56 \%$ but the lowest percentages happen on day 7 with $16.02 \%$ removal. The pretreatment percentage removal value was higher in day 9 may be because production of kitchen greywater was less and filter was enable to remove the suspended material due to low pressure from kitchen greywater. This situation happens because most greywater is high in organic load and therefore high in turbidity.

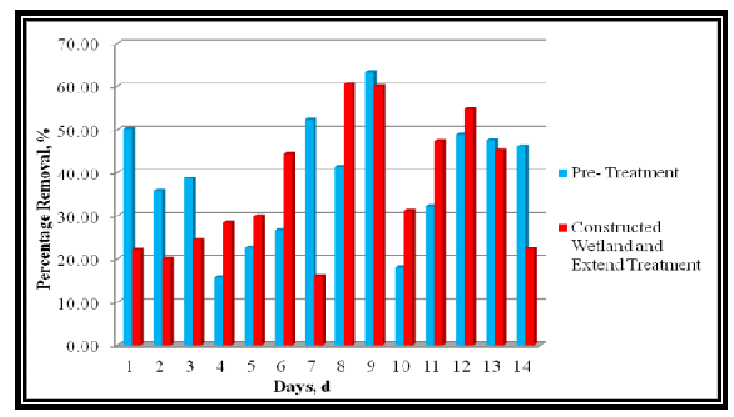

Figure 3: Percentage of Removal for Total Suspended Solid (TSS)

Bacteriological Reduction. As presented in Figure 4, the highest removal of E.coli in the filter recorded on the $10^{\text {th }}$ day with $42 \%$, while the lowest was recorded on the $4^{\text {th }}$ day with $8 \%$. The 
highest removal of E.coli in the constructed wetland plus extended treatment recorded on the $13^{\text {th }}$ day with $30 \%$, while the lowest was recorded on the $3^{\text {rd }}$ day with $17 \%$. Result indicates that filtration on pre-treatment process gives more efficiency on E.coli removal than constructed wetland. The negative value of percentage for the early operation on day 1 until day 8 may be due to capability of organism in wetland system to adapt and re-grow under acceptable conditions. In fact, E.coli require low concentrations of organic matter to grow [15]. Although, concentration of E.coli on vegetable was low than chicken depending on their existing contamination, material resource acquired and way of handling [16]. The concentration of E.coli in this study ranged from $5.7 \times 10^{3}$ to $12.7 \times 10^{3} \mathrm{CFU} / 100 \mathrm{mg}$. Compared to Matos et al., (2007) raw kitchen greywater recorded as range $1.3 \times 105-2.5 \times 10^{8} \mathrm{CFU} / 100 \mathrm{mg}$ of E.coli. Therefore, excessive E.coli from the kitchen greywater indicates allot of contamination in the water and need to be treated ecofriendly.

As presented in Figure 5 below, it shows the performance of whole constructed wetland system to removed E.coli. The highest percentage was obtained on day 10 with $51 \%$ removal, while the lowest percentage removal was recorded on day 3 with $26 \%$. Therefore, this means bacteria started to respond effectively with plants after a week of operation. This also indicates that plants also grow with time. Thus, it signifies that photosynthesis process for plant growth is a major consideration in the wetland system. Consequently, contaminant removal process such as bacterial degradation and adsorption take place in the plant roots.

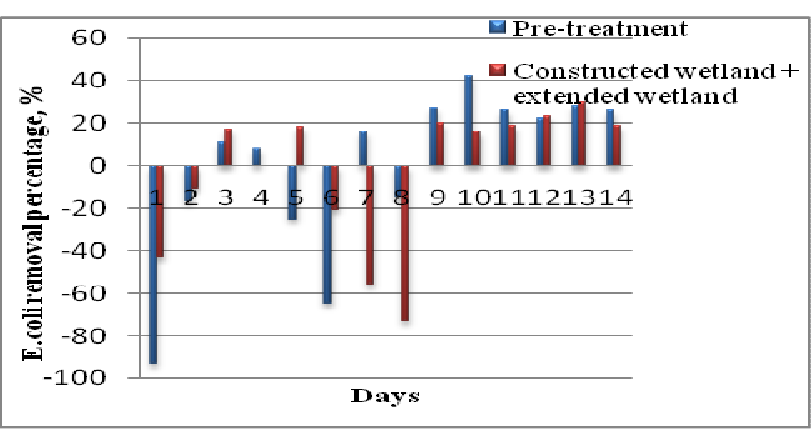

Fig. 4: E.coli removal for Pre-treatment and Wetland plus Extended Wetland

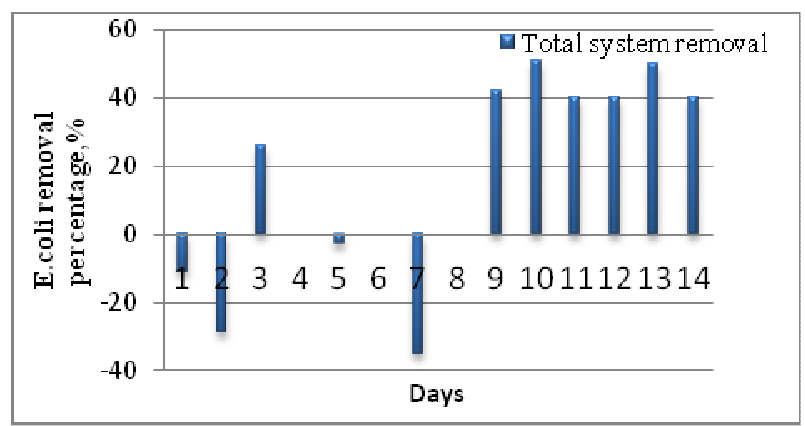

Fig. 5: E.coli removal for overall Constructed system of constructed wetland

Base on Figure 6 below, the highest reduction of Total coliform in the pre-treatment filter recorded on day 9 with $60 \%$, while the lowest was recorded on day 7 with $7 \%$ reduction. The highest reduction of Total Coliform in the constructed wetland plus extended treatment recorded on day 9 and day 10 with both achieving $70 \%$ of reduction, while the lowest was recorded on day 4 with $10 \%$. Result indicates that CW gives more efficiency on Total Coliform reduction than pretreatment system. These conform with previous writing that reduction of Total and Fecal Coliform in CW with emergent Macrophytes such as Lepironia Articulata is high, usually 95 to > 99\% [17]. From Figure 7, maximum percentage reduction was attained on day 8 with $63 \%$ reduction, while the lowest percentage was attained on day 7 with only $5 \%$ reduction. Thus, wetland plant play a role with its functions of photosynthetic process by releasing oxygen, contaminant reduction process such as bacterial degradation and adsorption to the wetland system. Hence, results from operating systems suggest that enteric microbe removal efficiency in CW with Lepironia Articulata is primarily influenced by hydraulic loading rate (HLR), the resultant hydraulic residence time (HRT) and the presence of vegetation. Removal of enteric bacteria follows approximately a first-order relationship. 


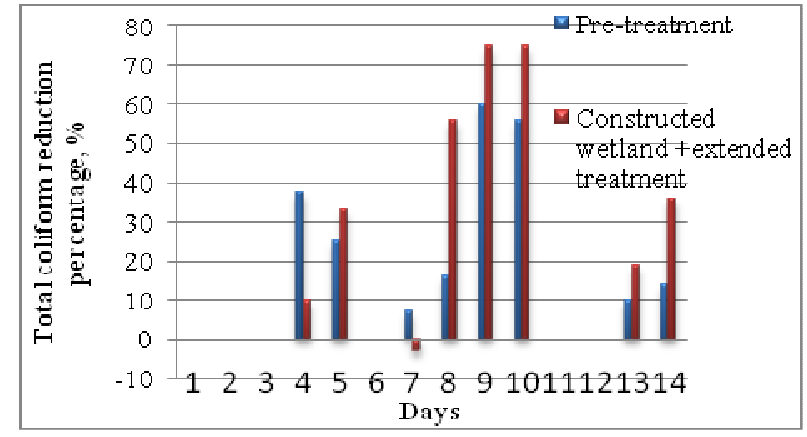

Figure 6: Total Coliform reduction for Pre-treatment, Constructed Wetland and Extended Treatment

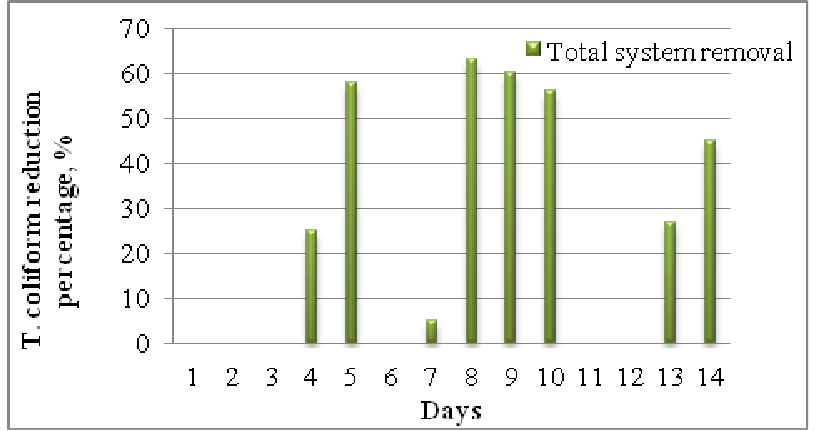

Figure 7: Total Coliform Reduction for Overall System of Constructed Wetland

\section{Conclusion}

From this study, efficiency of the treatment is good and wetland proves to be one of the alternatives for greywater treatment due to its simplicity of handling. Based on this study, it showed both total suspended solid (60.56\%), E.coli (51\%) and Total Coliform (63\%) are able to be reduced using horizontal constructed wetland system. The reduction of contaminant especially pathogen and another microorganism in kitchen greywater were important to reduce drain pollution at study area and decrease the risk of infection. As an alternative, the suitable design features of the constructed wetland, suitable plants and detail monitoring (maintenance) are important elements to achieve the objectives of constructed wetland as water quality improvement. In general, further greywater treatment should explore on lower plants as biotreatment with less or no maintenance issue.

\section{References}

[1] United Stated Environmental Protection Agency, Water Supply and Use in the United States, (2008) 7367, 2008.

[2] J. Sol, Arceivila, R. A. Shyam, Wastewater Treatment for Pollution Control And Reuse, Mc Graw Hill, 2008.

[3] R. M. S. R. Mohamed, C. M. Chan, H. Ghani, M. A. M. Yasin, and A. H. M. Kassim, Application of Peat Filter Media in Treating Kitchen Wastewater, International Journal of Zero Waste Generation 1, 1 (2013) 11-16.

[4] E. Eriksson, Potential and Problems Related To Reuse of Water In Household, Published by Environment and Resources, Technical University of Denmark. Muzola Aime, "SWITCH Sustainable Water Management in the City of the Future, 2007” (2001).

[5] B. L. Pangarkar, S. B. Parjane and M.G Sane, Design and Economical Performance of Gray Water Treatment Plant in Rural Region, (2010) 1-5.

[6] M. J. Travis, A. Wiel-Shafran, N. Weisbrod, E. Adar and A. Gross, Greywater reuse for irrigation: Effect on soil propertiesm, Science of the Total Environment, 408(12) (2010) 2501-2508. [7] S. H. C. Rani, M. Din, F. Md, M. Yusof, B. Mohd, and S. Chelliapan, Overview of Subsurface Constructed Wetlands Application in Tropical Climates, Universal Journal of Environmental Research \& Technology, 1(2) (2011).

[8] D. P. L. Rousseau, E. Lesage, A. Story, P. A. Vanrolleghem, and N. De Pauw, Constructed wetlands for water reclamation, Desalination, 218(1) (2008) 181-189.

[9] J. Vymazal, The use constructed wetlands with horizontal sub-surface flow for various types of wastewater, Ecological Engineering, 35(1) (2009) 1-17.

[10] A. Gross, D. Kaplan and K. Baker, Removal of chemical and microbiological contaminants from domestic greywater using a recycled vertical flow bioreactor (RVFB), Ecological engineering, 31(2), (2007) 107-114. 
[11] E. Eriksson, K. Auffarth, M. Henze and A. Ledin, Characteristics of grey wastewater. Urban water, 4(1), (2002) 85-104.

[12] S. Katayon, M. J. M. Mohd Noor, M. Asma, A. M. Thamer, A. G. L. Abdullah, A. Idris, A. M. Suleyman, M. B. Aminuddin and B. C. Khor, Effects of storage duration and temperature of Moringa oleifera stock solution on its performance in coagulation, International Journal of Engineering and Technology, 1(1), (2008) 46-151.

[13] G.S. Bilotta and R.E. Brazier, Understanding the influence of suspended solids on water quality and aquatic biota, Water Research, 42 (12), (2008) 2849-2861.

[14] G. O. Abakpa, V. J. Umoh, J. B. Ameh, and S. E. Yakubu, Microbial quality of irrigation water and irrigated vegetables in Kano State, Nigeria, International Food Research Journal 20, 5 (2013) 2933-2938.

[15] K. Raafat,Greywater treatment for reuse by slow sand filtration: study of pathogenic microorganisms and phage survival, Thèse N 2012 EMNA0051."Mémoire présenté en vue de l'obtention du grade de Docteur de l'Ecole des Mines de Nantes (2012).

[16] W. S. Chang, L. Afsah-Hejri, Y. Rukayadi, A. Khatib, Y. L. Lye, Y. Y. Loo, N. Mohd Shahril and R. Son, Quantification of Escherichia coli O157: H7 in organic vegetables and chickens, International Food Research Journal 20(2) (2013) 1023-1029.

[17] M. Greenway and C. Polson, Macrophyte Establishment in Stormwater Wetlands : Coping with flash flooding and fluctuating water levels in the subtropics, (2003) 1-10. 